Selcuk Journal of Agriculture and Food Sciences

http://sjafs.selcuk.edu.tr/sjafs/index

Review Article
SJAFS

(2020) 34 (1), 111-117

e-ISSN: $2458-8377$

DOI:10.15316/SJAFS.2020.203

\title{
Possible Effects of Climate Change on Weeds in Agriculture
}

\author{
Murat KARACA ${ }^{1, *}$, Sevda Serpil DURSUN ${ }^{1}$ \\ ${ }^{1}$ Selçuk University, Faculty of Agriculture, Department of Plant Protection, Konya, Turkey
}

\begin{tabular}{l}
\hline ARTICLE INFO \\
\hline Article history: \\
Received date: 25.10 .2019 \\
Accepted date: 01.04 .2020 \\
\hline Edited by: \\
Duran YAVUZ; Selçuk University, \\
Turkey \\
Reviewed by: \\
İlhan ÜREMIŞ; Hatay Mustafa Kemal \\
University, Turkey \\
Süleyman Gürdal TÜRKSEVEN; Ege \\
University, Turkey \\
\hline
\end{tabular}

Keywords:

Climate Change

Agriculture

Weeds

\begin{abstract}
In recent years, activities such as rapid population growth, industrialization, urbanization and unconscious consumption of natural sources, have many negative effects on natural balance. As a result of these negativities, environmental problems arise. Global warming is one of the environmental problems faced today. Global warming can be defined as, the process of overheating of the Earth more than it should be due to greenhouse gases, such as $\mathrm{H}_{2} \mathrm{O}$ (water vapor), $\mathrm{CO}_{2}$ (carbon dioxide) and $\mathrm{CH}_{4}$ (methane), slight prevention of sunlight reflecting from the Earth to the space. It is inevitable that, the rise of $\mathrm{CO}_{2}$ concentration due to the global warming and the changes in the precipitation regime and amount because of the heat will affect plants as a whole. As a matter of fact, different researchers presented that the climate change and increase in $\mathrm{CO}_{2}$ concentration cause alteration in plant growth, the rise in carbon dioxide affect the progress of cultivated plants in a positive way whereas, the rise in the heat and ozone affect the progress in a negative way. As a result of global warming, it can be thought that increasing $\mathrm{CO}_{2}$ amount will increase crop production in general. However, the existence of weeds, which cause serious losses in productivity and quality, refute this opinion. The genetic variability of the weeds, which are constantly competing against cultivated plants in terms of light and place, is quite rich when compared with cultivated plants. Therefore, they can adapt to any changes that occur in the environment. Ultimately, cultivated plants would be affected more by the differences caused by global warming. Moreover, as a result of climate change, the decrease in the event of herbicide activity, an effective weapon against the weeds, will make weeds much bigger matter.
\end{abstract}

\section{Introduction}

In recent years, rapid population growth, industrialization, urbanization and unconscious use of natural resources cause environmental problems (Y1ldiz et al 2000). Global warming is one of the environmental problems faced today.

It can be defined greenhouse gases known as $\mathrm{H}_{2} \mathrm{O}$ (water vapor), $\mathrm{CO}_{2}$ (carbon dioxide) and $\mathrm{CH}_{2}$ (methane), a variety of gases, the sun's rays reflected from the Earth after partially blocking the exit out of the atmosphere as a result of further warming of the Earth (Lynas 2008).

"Greenhouse gases" are gases of both natural and human origin that absorb and emit infrared radiation in the atmosphere (Fig. 1).

\footnotetext{
* Corresponding author email: mkaraca@selcuk.edu.tr
}

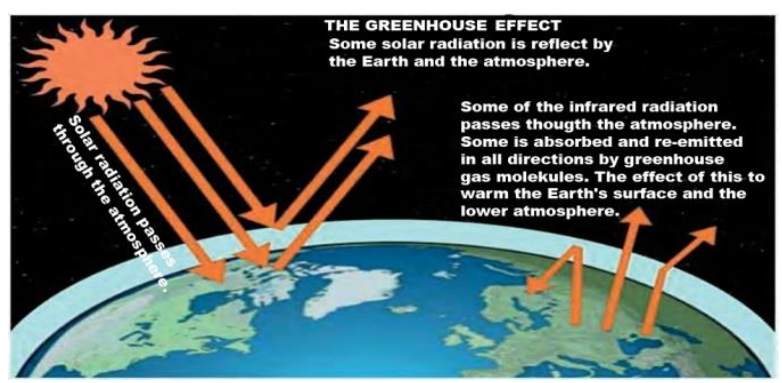

Figure 1

Greenhouse effect (Atabay et al., 2014)

Agricultural activities are responsible for about $20 \%$ of the world's growing greenhouse gases. So energy consumption, Plant Production, Animal Husbandry, fertilization, spraying, etc. in particular, $\mathrm{CO}_{2}, \mathrm{CH}_{4}$ and $\mathrm{N}_{2} \mathrm{O}$ are responsible for increasing greenhouse gases (Fig. 3) (Houghton 2003; Pathak \& Wassmann 2007).

Greenhouse gas emissions from carbon-source soils are increasing as a result of improper land use and unconscious and excessive fertilizing and pesticides (Fig. 4) (Lal 2006). The share of major greenhouse gases in global climate change is given in Figure 2. 


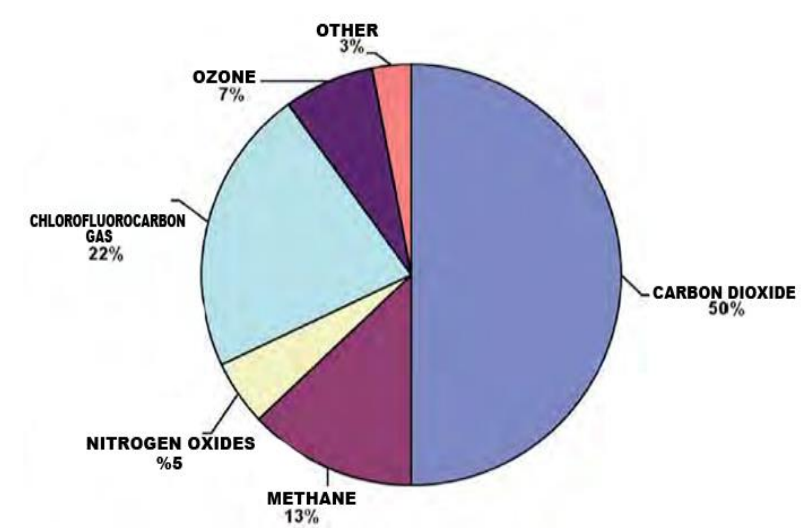

Figure 2

Share of greenhouse gases in global climate changes (Atabay et al 2014)

According to the Intergovernmental Panel on Climate Change (IPCC), atmospheric $\mathrm{CO}_{2}$ concentration increased by $31 \%$ over the last 250 years. The average global temperature has also increased by $0.6^{\circ} \mathrm{C}$ in the last hundred years (IPCC 2002).

\section{Turkey's Status}

Turkey has started to experience its driest seasons in recent years. It is observed that deviations in the amount and distribution of rainfall seen throughout our country have negative consequences in underground and above ground water reserves and that these deviations have continuity (Fig. 5; Fig. 6) (Türkeş 2001).

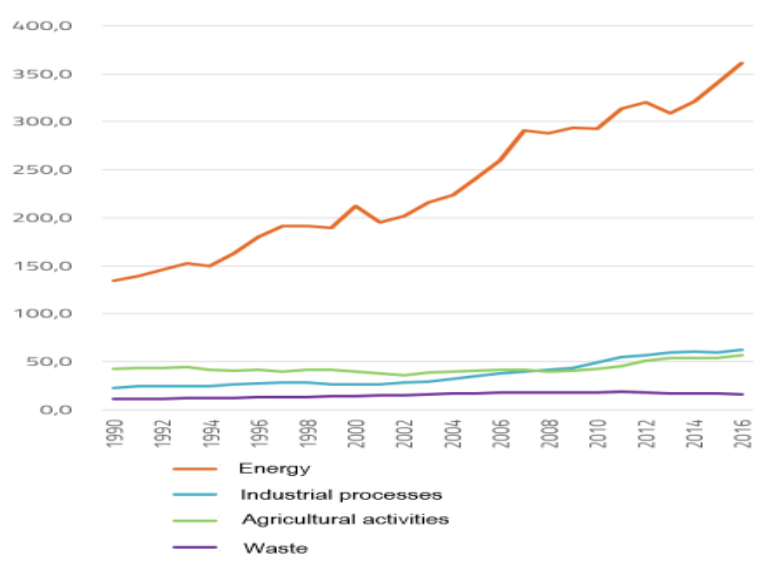

Figure 3

Development of greenhouse gas emissions by sector in Turkey 1990-2016 (Gündoğan 2018)

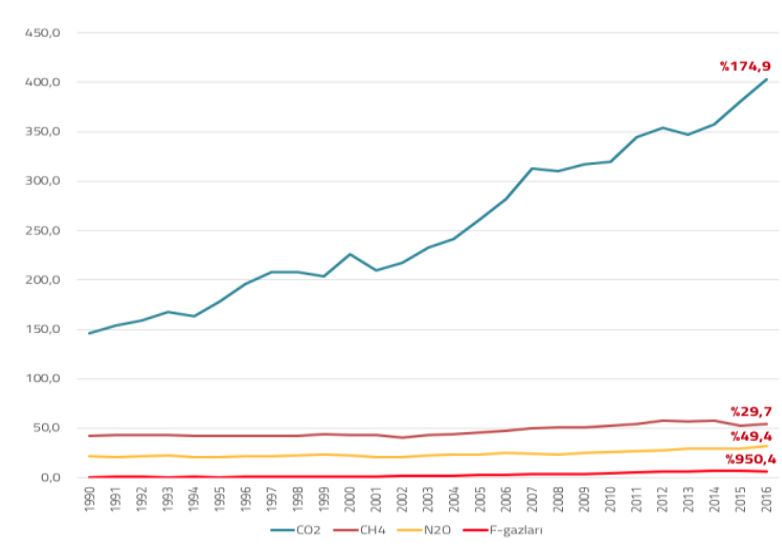

Figure 4

Development of greenhouse gas emissions by in Turkey (million tonnes) and change (\%) 1990-2016 (Gündoğan 2018)

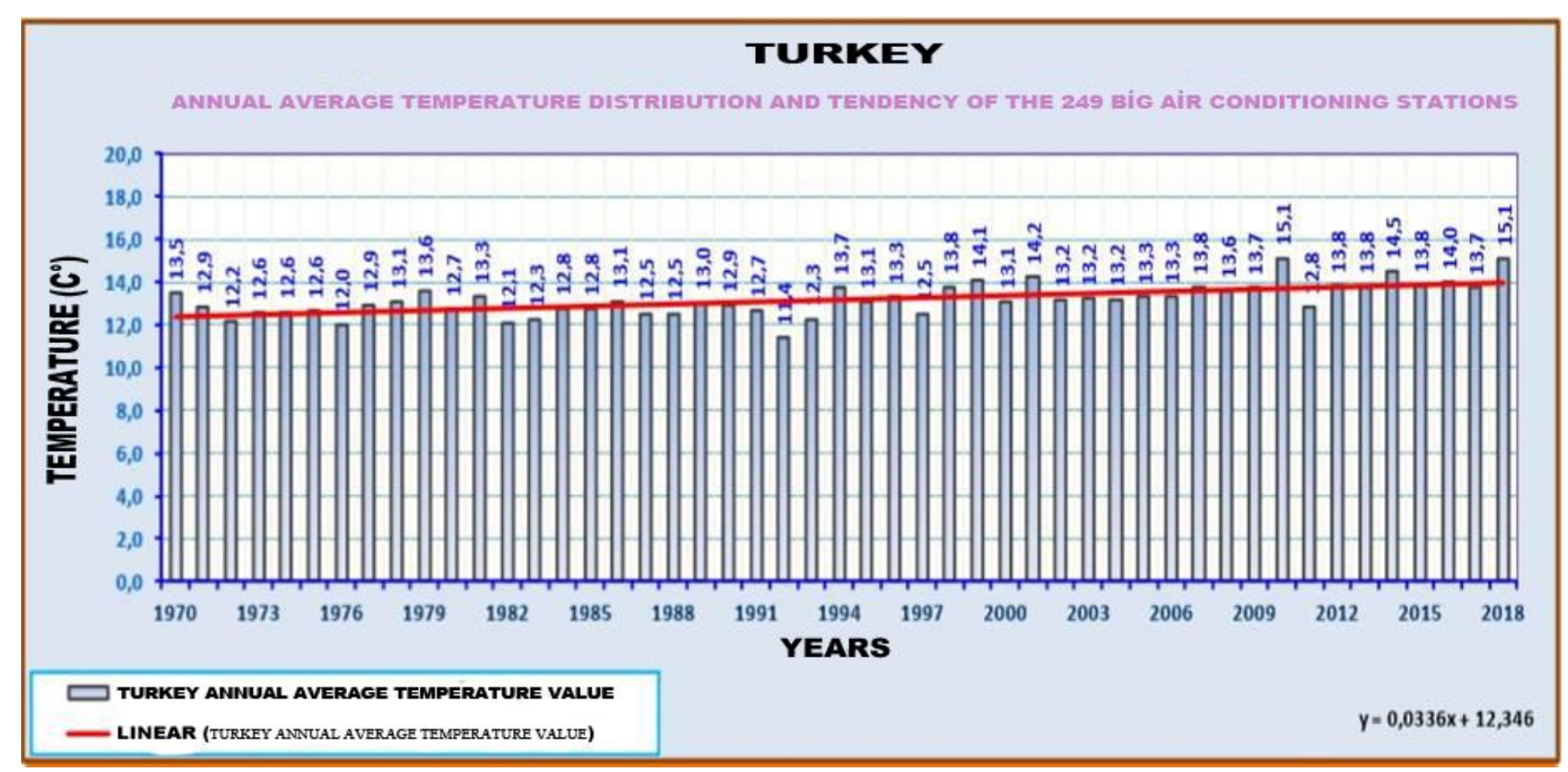

Figure 5

Turkey long-therm average temperature data (Anonymous 2019a) 


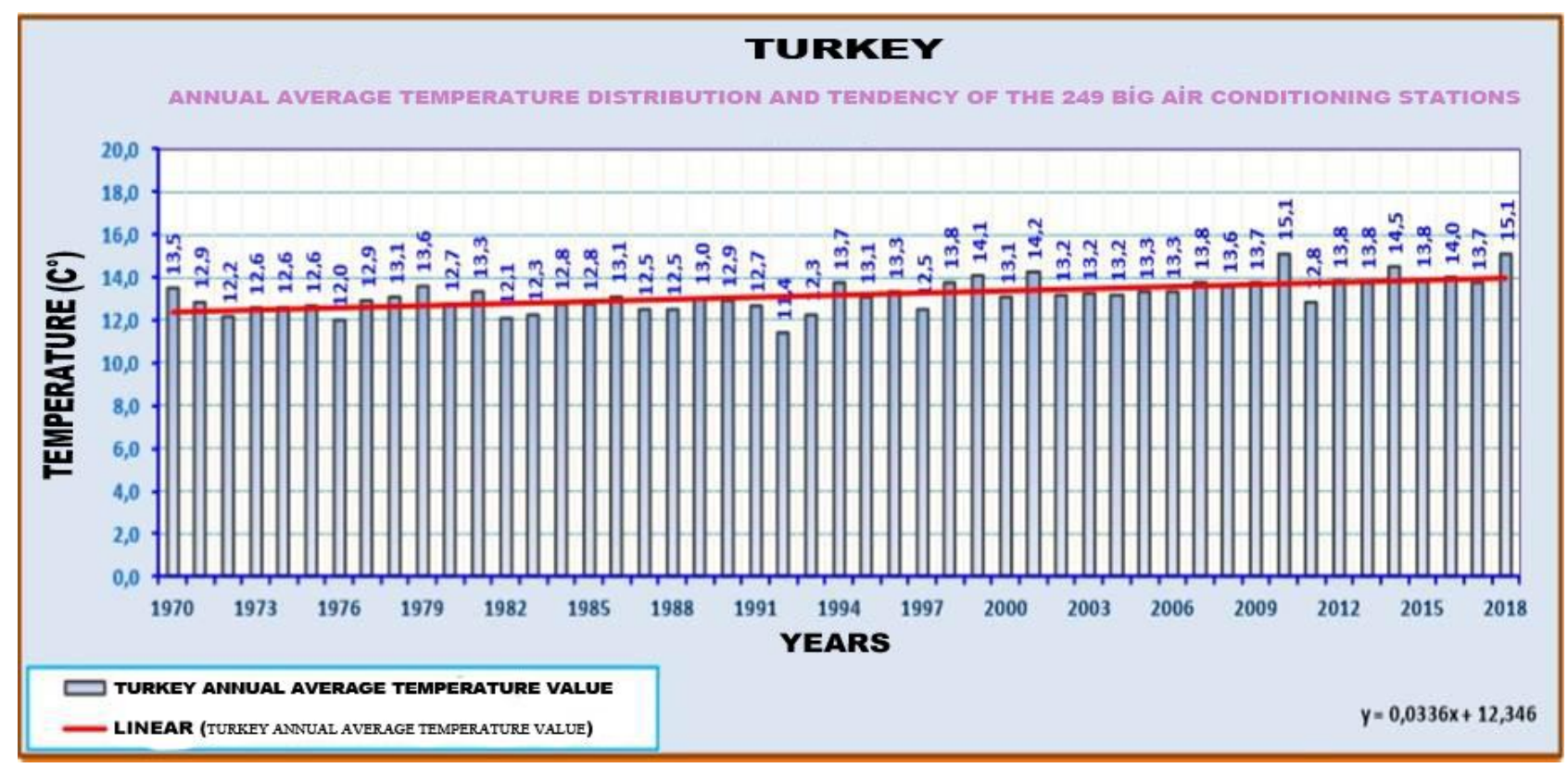

Figure 6

Long-term distribution of total annual precipitation data in Turkey (Anonymous 2019b)

\section{Impact of Climate Change on Weeds}

It has been shown that climate change and the increasing amount of $\mathrm{CO}_{2}$ have a positive effect on the growth of crop plants in general, while increasing temperature and ozone have a negative effect (Ainsworth \& Long 2005; Morgan et al 2006; Ainsworth 2008).

$\mathrm{C}_{3}$ plants are temperate climate plants that need high $\mathrm{CO}_{2}$ concentration, low temperature, and low ability to use light. $\mathrm{C}_{4}$ plants need low $\mathrm{CO}_{2}$ concentration, high temperature and lower water. They are resistant to seasonal drought and have a high ability to use light and are predicted to be adversely affected by the increased $\mathrm{CO}_{2}$ rate (Doğan \& Tüzer 2011).

Studies have shown that $\mathrm{C}_{3}$ plants respond better to the increased amount of $\mathrm{CO}_{2}$ than $\mathrm{C}_{4}$ plants (Heyman $\&$ Sadras 2010). In general, doubling the concentration of $\mathrm{CO}_{2}$ increases the biomass in $\mathrm{C}_{3}$ plants by about $40 \%$, while in $\mathrm{C}_{4}$ plants this rate remains at $11 \%$ (Kimball 1983). However, the level of increase varies greatly depending on the type of plant. As a result of the increased in $\mathrm{CO}_{2}$ concentration, growth in 27 herbaceous $\mathrm{C}_{3}$ plants increased by $79-272 \%$ and in 11 different $\mathrm{C}_{4}$ plants increased by $56-250 \%$ (Patterson \& Flint 1990).

Since plants other than sorghum, maize and sugarcane etc. are $\mathrm{C}_{3}$ plants, which are of global economic importance, it can be thought that climate change will give advantages to cultured plants and weeds will not pose a major problem. Furthermore, the fact that the important weeds that cause problems on earth are $\mathrm{C}_{4}$ plants in general supports this judgment.

For example, only 4 of the 18 most important weeds in the world are reported to be $\mathrm{C}_{3}$ plants (Holm et al 1977). However, one thing that is overlooked is that the number of species found in agricultural areas is far above that. It is the fact that these weeds, which under favorable conditions cause second degree damage, can replace others. Weed survey studies conducted in different cultivated plants in the world clearly reveal this situation (Uluğ et al 1993; Özer et al 2001).

Each cultured plant has its own unique weed and they are generally adapted to the production process of that cultured plant (Özer et al 2001). Wild oats, common Lamb's quarters, and barnyard grass are examples of wheat problems. In addition, the positive effect of the increase in the amount of $\mathrm{CO}_{2}$ when compared with the same photosynthesis method of cultured plants and weeds is in favor of weeds.

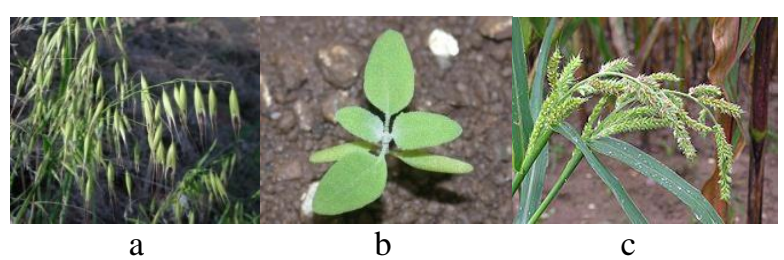

Figure 7

a) Avena fatua b) Chenopodium album

c) Echinochloa crus-galli (Anonymous 2019c)

According to Patterson (1995), 2 times the amount of $\mathrm{CO}_{2}$ increases the total weight of weeds by an average of $130 \%$ in $\mathrm{C}_{3}$ weeds and $115 \%$ in $\mathrm{C}_{4}$ weeds. Both $\mathrm{C}_{4}$ and $\mathrm{C}_{3}$ weeds will continue to pose problems in plantation as they adapt rapidly to new environmental conditions created by global warming. Even if the effectiveness of $\mathrm{C}_{4}$ weeds decreases in agricultural areas due to increased temperature and $\mathrm{CO}_{2}$, it is likely that $\mathrm{C}_{3}$ weeds will be replaced immediately.

\subsection{Effect on Weed-Crop Competition}

Depending on the type of crop plant and weeds, competition is sometimes expected to change in favor 
of cultured plant and sometimes weeds (Patterson, 1995). However, high $\mathrm{CO}_{2}$ conditions are generally expected to make $\mathrm{C}_{3}$ weeds more competitive (Ziska 2000).

Indeed, one study found that the ability of soybeans to respond positively to increased carbon dioxide is reduced by weeds. In competition with Chenopodium album, a $\mathrm{C}_{3}$ weed, the decline in soybean yield was highest. However, when it competes with a $\mathrm{C}_{4}$ plant, the redroot pigweed (Amaranthus retroflexus), the intensity of the competition was lower.

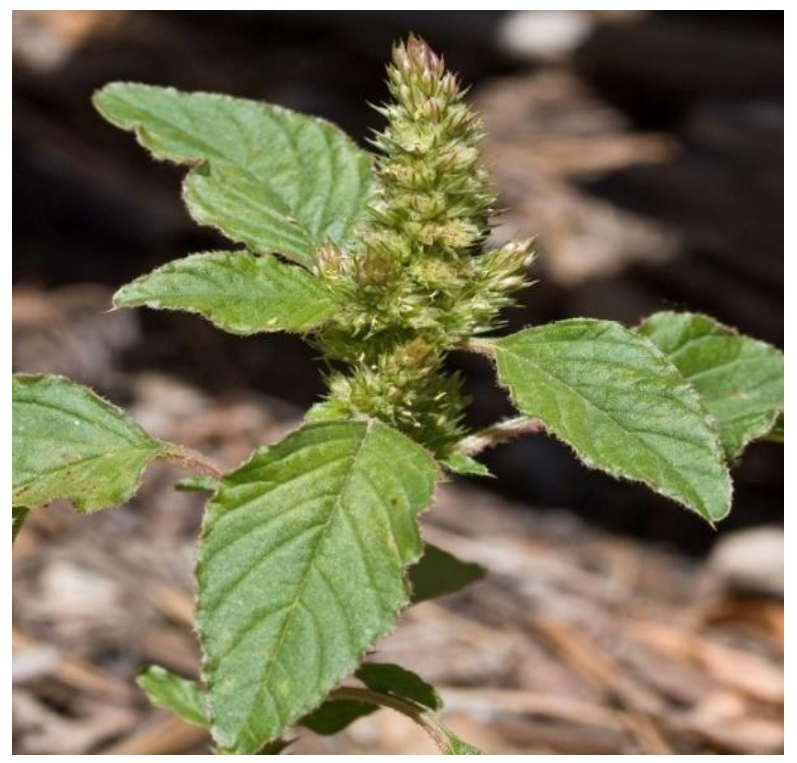

Figure 8

Amaranthus retroflexus (Anonymous 2019d)

\subsection{Effect on Perennial Weeds and Herbicides}

The control of perennial weeds is extremely difficult as it depends on the elimination of vegetative reproductive organs. For success it often has to be applied together with the use of the herbicide with mechanical control.

However, due to the increase in photosynthesis products, the increase is expected in vegetative reproductive organs such as rhizome, stolon, and root. While this increase will lead to an increase in the vegetative reproductive capacity of perennial weeds, it will also make it more difficult to control.

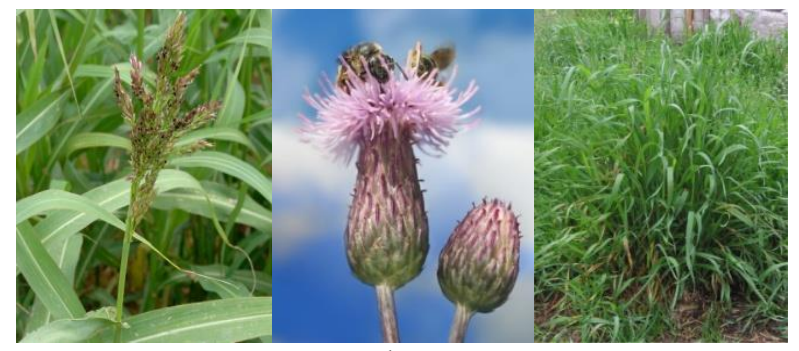

a

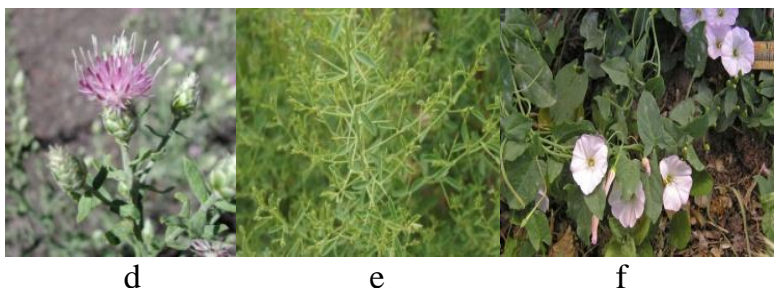

Figure 9

Some perannual weeds

a) Sorghum halepense, b) Cirsium arvense, c) Acroptilon repens, d) Elymus repens, e) Alhagi pseudalhagi, f) Convolvulus arvensis (Anonymous 2019e)

In addition, differences in the structure of weeds leaves and reasons such as the accumulation of starch in the leaves of $\mathrm{C}_{3}$ plants lead to a decrease in the effect of herbicides used (Figure 10). Therefore, climate changes probably suggest that perennial weeds, especially invasive species, will increase in agricultural areas and become a bigger problem (Ziska \& Teasdale 2000; Ziska et al 2004; Ziska 2008).

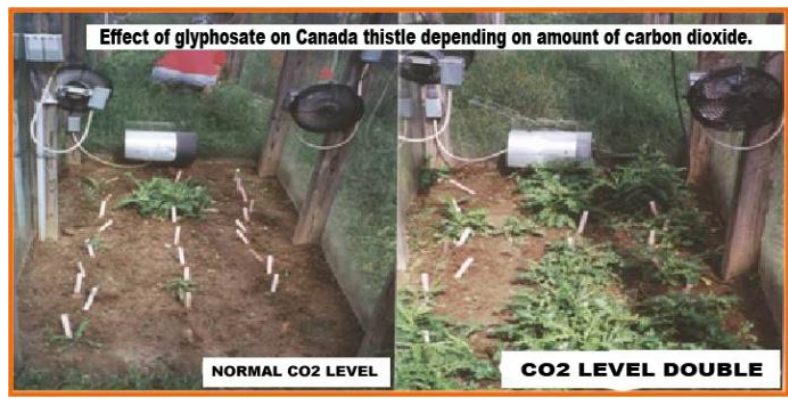

Figure 10

Effect of glyphosate on Cirsium arvense depending on the amount of carbon dioxide (Ziska 2010)

\subsection{Impact of Climate Change on Invasive Plants}

Studies under controlled conditions suggest that the response of invasive plants to climate change, especially $\mathrm{CO}_{2}$ increases, is generally higher than that of local species (Willis et al 2010).

The increase in temperature is also thought to trigger the growth of invasive plants and thus cause them to complete their life span in a shorter time than normal. Thus, it is estimated that plants may show higher fertility and increase their spread (Burke \& Grime 1996; Blicker et al 2002; Kolb et al 2002; Morris et al 2002; Gerlach \& Rice 2003; Leger \& Rice 2003). 


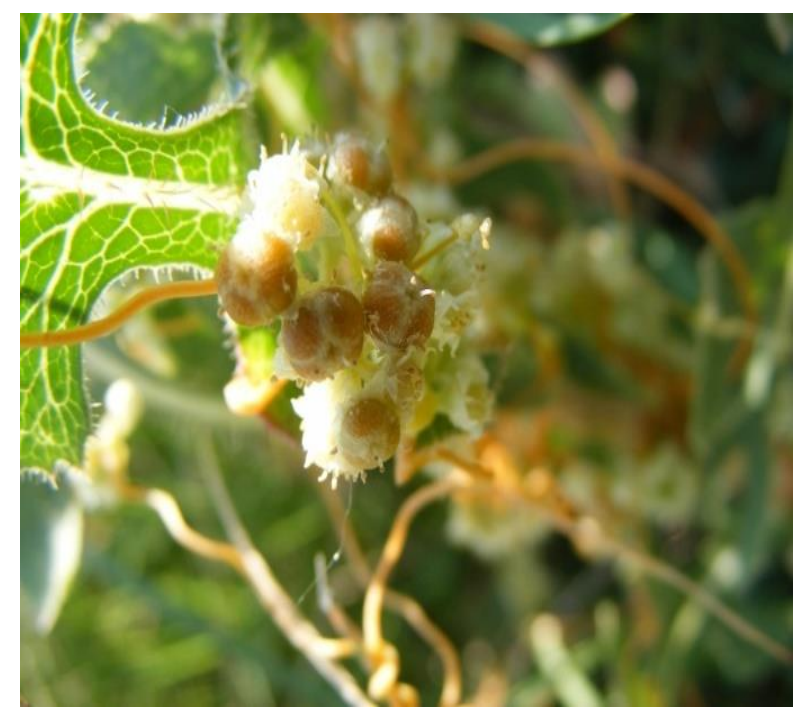

Figure 11

Invasive parasite weed Cuscuta campestris Yunck. (Tamer 2012)

\section{Weed Control Due to Climate Change}

Herbicides are one of the most effective weapons in weed control. Reduced herbicide activity due to climate change will make weeds a much bigger problem (Ziska 1998; 2008; Ziska \& Goins 2006). In addition, environmental stress conditions affecting cultured plants will also make cultured plants more susceptible to disease, pest and weed competition (Patterson 1995). This puts the management of weeds, which are a problem in agricultural fields due to climate change, in a much more important position. Indeed, yield losses from weeds are expected to increase.

\section{Example Studies of Importance}

Elymus repens (quack grass) growth, photosynthetic activity and tolerance observed under conditions of increased $\mathrm{CO}_{2}$ glyphosate the chemical management in seeking to it was concluded that it would be difficult perennial weeds (Ziska \& Teasdale 2000).

Ziska and Faulkner (2004), investigated the effectiveness of normal and augmented $\mathrm{CO}_{2}$ conditions on the growth, biomaterial and glyphosate susceptibility of village references: canada thistle (Cirsium arvense). According to the results, it is stated that in the future, the chemical control of canada thistle and other perennial weeds will be difficult under high $\mathrm{CO}_{2}$ conditions.

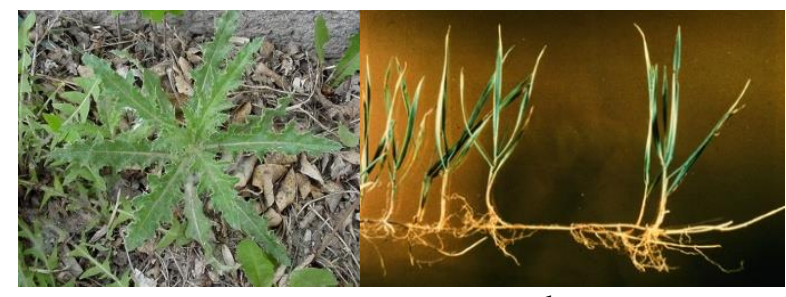

a

b

Figure 12

a) Cirsium arvense, b) Elymus repens (Anonymous, 2019f)
Hobbs and Mooney (2005) reported that while climate change affects biodiversity on the one hand, it also promotes biological invasions from weed species that can easily adapt to extreme conditions. Loss of biodiversity due to biological invasions becomes even more serious due to climate change.

Stinson and Bazzaz (2006) found that high $\mathrm{CO}_{2}$ administration increased the reproductive capacity and biomaterial of the invasive weed, Ambrosia artemisiifolia. Rogers et al (2008) investigated the effects of increased $\mathrm{CO}_{2}$ on the growth of Cyperus rotundus and C. esculentus. The study concluded that these two invasive species would be more likely to spread in the future.

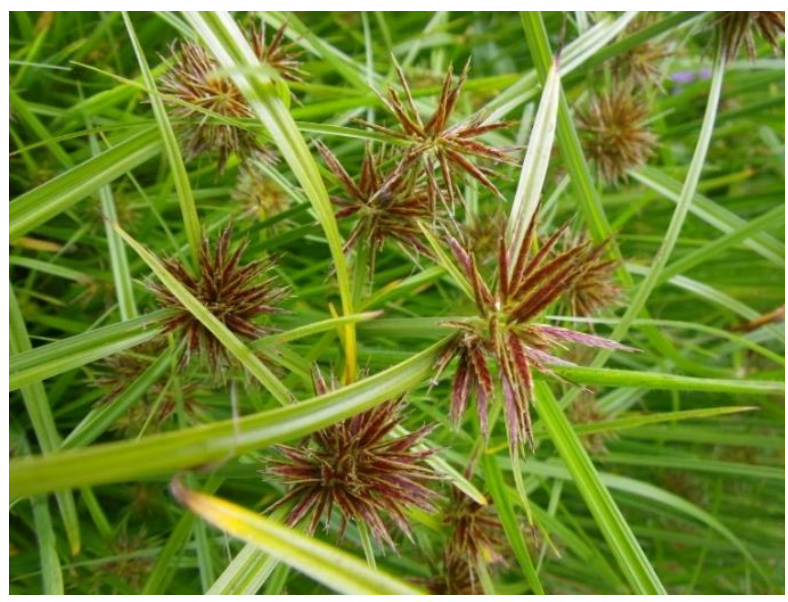

Figure 13

Cyperus rotundus (Anonymous 2019g)

Göncü (2013), in his study corn of different $\mathrm{CO}_{2}$ ratios (Zea mays L.), the problem in Sorghum halepense, Echinochloa cruss-galli, Amaranthus blitoides and Solanum nigrum's growth, competition and herbicide sensitivity was aimed to determine. The high $\mathrm{CO}_{2}$ ratio positively affected the output of some weeds. In normal $\mathrm{CO}_{2}$ conditions weeds reduced maize growth, while in high $\mathrm{CO}_{2}$ conditions there was no decrease in growth. It has been determined that the growth parameters of weeds reach higher values in high $\mathrm{CO}_{2}$ and competitive conditions. It has also been determined that generally high $\mathrm{CO} 2$ conditions can cause a decrease in herbicide activity.

Meșe (2014)' s research aimed to determine the growth, competition and herbicide susceptibility of weeds of Avena sterilis, Phalaris minor, Galium tricornutum, Sinapis arvensis, which are problems in wheat of different $\mathrm{CO}_{2}$ ratios. Weed competition has caused a decrease in wheat growth in different $\mathrm{CO}_{2}$ conditions. Weed growth was not affected by $\mathrm{CO}_{2}$ in the non-competitive environment, while reductions were seen in the competitive environment. It has also been observed that herbicide sensitivity is lower in narrow-leaved weeds and increased in broad-leaved weeds.

Over the past few decades, significant transformations have been induced by changing climate in the weed flora of agroecosystems, worldwide, allowing 
thermophile, late-emerging weeds, and some opportunistic weeds to become more abundant in some cropping systems. Increasing $\mathrm{CO}_{2}$, as the most important greenhouse gas, affects plants by changing the species distribution, alteration in reproduction timing and length of growing seasons. Climate change directly influences arable weeds through raising the temperature and changing the precipitation pattern (Peters et al 2014).

Jabran and Doğan (2015) examined the effect of normal and 2 times dose $\mathrm{CO}_{2}$ ratio on the growth of Lolium perenne and Medicago sativa. As a result of the trial, L. with increased $\mathrm{CO}_{2}$ application positive relationship between age-dry weight and chlorophyll content of perenne plants was determined. $M$. sativa, however, the overall $\mathrm{CO}_{2}$ increase was not affected by age and dry weight.

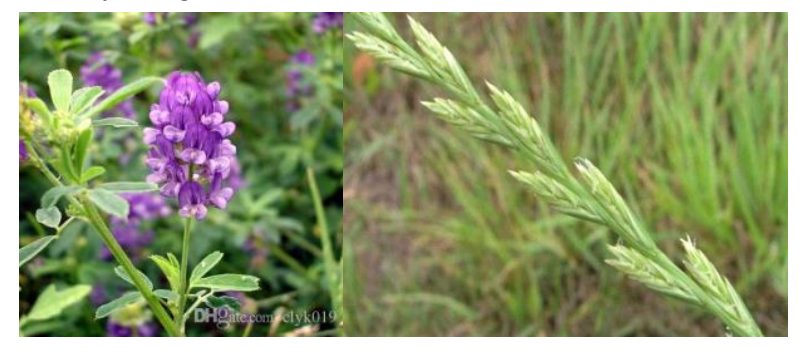

a

b

Figure 14

a) Medicago sativa, b) Lolium perenne (Anonymous, 2019h)

Jabran et al (2015) evaluated the effect of ambient (current level of $\mathrm{CO}_{2}$ in the atmosphere) and simulated (double of normal $\mathrm{CO}_{2}$ ) $\mathrm{CO} 2$ levels on the invasive weed species Potentilla recta $\mathrm{L}$. The invasive weed species was grown under normal ( 400 ppm) and elevated ( $~ 800-850 \mathrm{ppm}) \mathrm{CO}_{2}$ in a controlled glasshouse. The data about fresh weight, dry weight, number of leaves, plant height and chlorophyll index were recorded. The studies indicated that the elevated $\mathrm{CO}_{2}$ levels increased the growth of $P$. recta. The high levels of $\mathrm{CO}_{2}$ increased the fresh weight, dry weight, plant height and number of leaves of $P$. recta compared with ambient $\mathrm{CO}_{2}$ while chlorophyll index was not affected.

Tursun et al (2018) conducted a study to determine the reactions of some weeds (Amaranthus retroflexus, Portulaca oleracea, Physalis angulata, Sorghum halepense) to different $\mathrm{CO}_{2}$ concentrations and different temperatures under greenhouse conditions. As a result of the study, parallel to the increase in $\mathrm{CO}_{2}$, even if there is some positive growth in plants, they stated that the increase in environmental temperature would negatively affect crops and agriculture.

\section{Conclusion and Recommendations}

Studies have shown that the increased $\mathrm{CO}_{2}$ concentration associated with climate change can have positive reactions to the growth of cultivated plants such as corn, cotton, soybean, wheat, and rice (Alberto et al 1996; Ziska \& Bunce 1997; Reddy et al 1999; Ziska 2000; Ziska \& Goins 2006; Patel et al 2008; Zhu et al
2008; Erbs et al 2009). However, there are also findings that reactions to changes in weeds may be higher than in cultured plants (Ziska \& Bunce, 1993; Ziska \& Bunce 1997; Ziska 2002; Pandey et al 2003). Therefore, it is a fact that changing conditions will affect weed-crop competition. Changes in the methods of management weeds will be inevitable.

Determination of the adaptation potentials of weeds to climate changes should be one of the priority objectives of weeds science (Neve et al 2009). However, it has not yet been fully revealed how factors such as temperature, amount of $\mathrm{CO}_{2}$, light and water in field conditions affect weed growth and the effectiveness of herbicides. Therefore, detailed studies on this subject are needed to reach a final judgment.

It is known that climate change can significantly affect the growth, reproduction, distribution, competitiveness, etc. of invasive plants. It also suggests that the species in question will increase, especially in agricultural areas, and become a bigger problem (Ziska \& Teasdale 2000; Ziska et al 2004; Ziska 2008). Therefore, invasive plants need to be dealt with again and more carefully in the context of the possible impacts of climate change.

\section{References}

Ainsworth EA, Long SP (2005). What have we learned from 15 years of free-air $\mathrm{CO}_{2}$ enrichment? A metaanalytic review of the responses of photosynthesis, canopy properties and plant production to rising $\mathrm{CO}_{2}$. New Phytologist, 165: 251-371.

Ainsworth EA (2008). Rice production in a changing climate: a meta-analysis of responses to elevated carbon dioxide and elevated ozone concentration. Global Change, 14:1642-1650.

Alberto AMP, Ziska LH, Cervancia CR, Manalo PA (1996). The influence of increasing carbon dioxide and temperature on competitive interactions between a C3 crop, rice (Oryza sativa) and a C4 weed (Echinochloa glabrescens). Australian Journal of Plant Physiology, 23 (6): 795-802

Anonymous (2019a). https://www.mgm.gov.tr/FILES/resmi istatistikler/parametreAnalizi/Turkiye-Ortalama-Sicaklik.pdf 26.08.2019

Anonymous (2019b). https://www.mgm.gov.tr/FILES/resmi istatistikler/parametreAnalizi/Turkiye-Yagis.pdf 26.08.2019

Anonymous (2019c). http://swbiodiversity.org/seinet/taxa/index.php?taxon= Avena\%20fatua\#

https://weedecology.css.cornell.edu/weed/weed.php?id=8 https://en.wikipedia.org/wiki/Echinochloa_crus-galli 18.09.2019

Anonymous (2019d). https://www.flickr.com/photos/dougcwaylett/2714444 $\underline{941}$ 
Anonymous (2019e). https://en.wikipedia.org/wiki/Cirsium_arvense

https://www.sorhocam.com/etiket.asp?sid=7647\&sorghu m-halepense/http://swbiodiversity.org/ seinet/taxa/index.php?taxon=2736\&clid=69https://en. wikipedia.org/wiki/Elymus_repens

https://www.gezenadam.com/flora/AI.php?ID=542

https://www.swcoloradowildflowers.com/White\%20Enlar ged\%20Photo\%20Pages/convolvulus\%20arvensis.htm 20.09.2019

Anonymous (2019f). https://www.reddit.com/r/gardening/comments/1d4igs/ battling_canada_thistle_anyone_know how to_kill/

$\underline{\text { http://agron- }}$

www.agron.iastate.edu/ weeds/AG517/WeedID/quac kg.html 22.09.2019

Anonymous (2019g). https://www.devonpondplants.co.uk/product/cyperusrotundus/ 24.09.2019

Anonymous (2019h). https://tr.dhgate.com/product/alfalfa-seeds-perennial$\underline{\text { medicago-sativa-seeds/409059355.html }}$

https://antropocene.it/en/2019/06/14/lolium-perenne/ 25.09.2019

Atabay S, Karasu M, Koca C (2014). İklim Değişikliği ve Geleceğimiz, Y.T.Ü. Kütüphane ve Dokümantasyon Merkezi. ISBN: 978-975-461-513-5

Blicker PS, Olson BE, Engel R (2002). Traits of the invasive Centaurea maculosa and two native grasses: effect of N supply. Plant Soil., 247, 261-269.

Burke MJW, Grime JP (1996). An experimental study of plant community invasibility. Ecology, 77, 776-790.

Doğan S, Tüzer M (2011). Küresel iklim değişikliği ve potansiyel etkileri, C.Ü. İktisadi ve İdari Bilimler Dergisi, 12(1), 21-34.

Erbs M, Franzaring J, Högy P, Fangmeier A (2009). Freeair $\mathrm{CO}_{2}$ enrichment in a wheat-weed assembly- effect on water relations. Basic and Apllied Ecology, 10: 358-367.

Gerlach JD, Rice KJ (2003). Testing life history correlates of invasiveness using congeneric plants species. Ecol. Appl., 13, 167-179.

Göncü GB (2013). Farklı $\mathrm{CO}_{2}$ Oranlarının Misır (Zea mays L.)'da Bazı Önemli Yabancı Otların Gelişimi, Rekabeti ve Herbisit Duyarlılığına Etkisi. ADU, FBE, Yükseklisans Tezi, 71s.

Gündoğan AC (2018). Türkiye Sea Gazı Emisyon İstatistiklerine Yakın Bakış. İklim Haber Bülteni. https://www.iklimhaber.org/turkiye-sera-gaziemisyon-istatistiklerine-yakin-bakis/ 17.09.2019

Heyman P, Sadras V (2010). Climate change and weed management in Australian farming systems. http://www.caws.org.au/awc/2006/awc200610221.pdf. Fifteenth Australian Weeds Conference.

Hobbs RJ, Mooney HA (2005). Invasive species in a changing world: the interactions between global change and invasives. In Invasive alien species. A new synthesis (eds Mooney H.J., Mack R.N., Mcneely
J.A., Neville L.E., Sche1 P.J., Waage J.K.) Washington, DC: Island Press.pp. 310-331.

Holm LG, Plucknett DL, Pancho JV, Herberger JP (1977). The world's worst weeds: Distribution and biology. University of Hawaii Press, Honolulu.

Houghton RA (2003). Why Are Estimates of The Terrestrial Carbon Balance So Different? Global Change Biology, v. 9, p. 500- 509

IPCC (2002). Climate Change and Biodiversity, Eds by: Gitay, H., Saurez, A., Watson, R.T. and Dokken, D.J. IPPC (Intergovermantal panel on Climate Change)Tecnical paper 5, ISBN: 92-9169-104-7, pp. 76.

Jabran K, Doğan MN (2015). İki İstilacı Bitkinin Normal ve Değiştirilmiş $\quad \mathrm{CO}_{2}$ Konsantrasyonları Altında Gelişimleri. İstilacı Bitkiler Çalıştayı, 22 Mayıs. S. 46.

Jabran K, Doğan MN, Eren Ö (2015). Effect of ambient and simulated $\mathrm{CO}_{2}$ on the growth of invasive weed Potentilla recta L. Agriculture and Forestry, 61 (1): 107-112.

Kimball BA (1983). Carbondioxide and agriculturaly yield: an assemblage and analysis of 770 prior observations. WCL Report 14. U.S. Water Conserv. Lab., U.S. Dep. Agric. Agric. Res. Serv., Phoenix, AZ.

Kolb A, Alpert P, Enters D, Holzapfel C (2002). Patterns of invasion within a grassland community. J Ecol., 90, 871-881.

Lal R (2006). Enhancing Crop Yields in The Developing Countries Through Restoration of The Soil Organic Carbon Pool in Agricultural Lands. Land Degradation and Development, v. 17, p. 197- 209

Leger EA, Rice KJ (2003). Invasive California poppies (Eschscholzia californica Cham.) grow larger than native individuals under reduced competition. Ecol Lett., 6, 257-264.

Lynas M (2008). 6. Derece (çev. D. Akın, K. Kutlu ve E. Serhat). İstanbul: NTV Yayınları.

Meşe G, Doğan MN (2015). Influence of Different $\mathrm{CO}_{2}$ Levels on the Growth And Competition of Some Important Weeds in Wheat (Triticum aestivum L.). Agriculture \& Forestry, Vol. 61, Issue 1: 35-39, DOI: 10.17707/AgricultForest.61.1.04

Morgan PB, Mies TA, Bollero GA, Nelson RL, Long SP (2006). Seasonlong elevation of ozone concentration to projected 2050 levels under fully open-air conditions substantially decreases the growth and production of soybean. New Phytologist, 170: 333-343.

Morris LL, Walck JL, Hidayati SN (2002). Growth and reproduction of the invasive Ligustrum sinense and native Forestiera ligustrina (Oleaceae): implications for the invasion and persistence of a nonnative shrub. Int J Plant Sci., 163, 1001-1110.

Neve, Vila-Aiub PM, Roux F (2009). Ebolutionarythinking in agricultural weed management. New Phytologist, 184: 783-793.

Özer Z, Kadıŏglu İ, Önen H, Tursun N (2001). Herboloji (Yabanci ot bilimi- 3. baskı) Gaziosmanpaşa Üniversitesi Ziraat Fakültesi, Yayınları no:20, Kitap Serisi No:10, Tokat. 
Pandey DK, Palni LMS, Joshi SC (2003). Growth, reproduction, and photosynthesis of ragweed parthenium (Parthenium hysterophorus). Weed Science, 51(2): 191-201.

Patel HR, Patel VJ, Pandey V (2008). Impact assessment of climate change on maize cultivars in middle Gujarat agro-climatic region using CERES maize model. Journal of Agrometeorology, 10 (2): 292-205.

Pathak H, Wassmann R (2007). Introducing Greenhouse Gas Mitigation as a Development Objective in RiceBased Agriculture: I. Generation of Technical Coefficients. Agricultural Systems 94: 807- 825.

Patterson DT, Flint EP (1990). Implications of increasing carbon dioxide and climate change for plant communities and competition in natural and managed ecosystems. Pages 83-110 in B. A. Kimball, N. J. Rosenberg, and L. H. Allen, Jr., eds.,

Patterson DT (1995). Weeds in a changing climate. Weed Science, 43:685-701.

Peters K, Breitsameter L, Bärbel Gerowitt B (2014). Impact of climate change on weeds in agriculture: a review. Agron. Sustain. Dev., 34:707-721.

Reddy KR, Davidonis GH, Johnson AS, Vinyard BT (1999). Temperature regime and carbon dioxide enrichment alter cotton boll development and fiber properties. Agron. J. 91:851-858.

Rogers Jr HH, Runion GB, Prior SA, Price AJ, Torbert III HA, Gjerstad DH (2008). Effects of elevated atmospheric $\mathrm{CO}_{2}$ on invasive hlants, comparison of purple and yellow nutsedge (Cyperus rotundus and C. esculentus). Journal of Environmental Quality, 37: 395400.

Stinson KA, Bazzaz FA (2006). $\mathrm{CO}_{2}$ enrichment reduces reproductive dominance in competing stands of $\mathrm{Am}$ brosia artemisifolia (common ragweed). Oecologia, 147: 155-163.

Tamer ŞR (2012). Farklı Sıcaklıkların, Bazı Yeşil Gübrelerin ve Bitki Eksudatlarının Küskütün (Cuscuta campestris (L.) Yunck.; C. approximata Bab.) Çimlenmesi Üzerine Etkileri. Ege Üniversitesi, Fen Bilimleri Enstitüsü, Yüksek Lisans tezi. 74

Tursun N, Üremiş İ, Bozdoğan O, Doğan MN (2018). Sıcaklık ve $\mathrm{CO}_{2}$ artışlarına bazı önemli yabancı otların verdikleri tepkilerin araştırılması. Erciyes Üniversitesi, Fen Bilimleri Enstitüsü Dergisi. 34(3):26-35

Türkeş M (2001). Hava, İklim, Şiddetli Hava Olayları ve Küresel Isınma. İçinde: T.C. Başbakanlık Devlet Meteoroloji İşleri Genel Müdürlüğü 2000 Y1lı Seminerleri, Teknik Sunumlar, Seminerler Dizisi 1: 187-205, Meteoroloji Genel Müdürlügü: Ankara.
Uluğ E, Kadıŏlu İ, Üremiș İ (1993). Türkiye'nin Yabancı Otları ve Bazı Özellikleri, Zirai Mücadele Araştırma Enstitüsü Müdürlügü, Yayın No:78, Adana

Willis CG, Ruhfel BR, Primack RB, Miller-Rushing AJ, Losos JB, Davis CC (2010). Favorable climate change response explains non-native species success Inthoreau's woods. PLoS ONE 5(1): e8878. doi: 10.1371/journal.pone.0008878

Yıldız K, Sipahioğlu Ş, Yılmaz M (2000). Çevre bilimi. Ankara: Gündüz Eğitim ve Yayıncılık.

Zhu CW, Zeng Q, Ziska LH, Zhu JG, Xie ZB, Liu GL (2008). Effect of nitrogen supply on carbon dioxideinduced changes in competition between rice and barnyardgrass (Echinochloa crus-galli). Weed Science, 56 (1): 66-71.

Ziska LH, Bunce AJ (1993). The influence of elevated $\mathrm{CO}_{2}$ and temperature on seed germination and emergence from soil. Field Crops Research, 34 (2): 147157.

Ziska LH, Bunce AJ (1997). Influence of increasing carbon dioxide concentration on the photosynthetic and growth stimulation of selected $\mathrm{C}_{4}$ crops and weeds. Photosynthesis Research, 54: 199-208.

Ziska LH (2000). The impact of elevated $\mathrm{CO}_{2}$ on yield loss from $\mathrm{C}_{3}$ and $\mathrm{C}_{4}$ weed in field-grown soybean. Global Change Biology, 6, 899-905

Ziska LH, Teasdale JR (2000). Sustained growth and increased tolerance to glyphosate observed in a C-3 perennial weed, quackgrass (Elytrigia repens), grown at elevated carbon dioxide. Australian Journal of Plant Physiology, 27(2), 159-166

Ziska LH (2002). Influence of rising atmospheric $\mathrm{CO}_{2}$ since 1900 on early growth and photosynthetic response of a noxious invasive weed, canada thistle (Cirsium arvense). Functional Plant Biology, 29: 1387-1392.

Ziska LH, Faulkner S, Lydon J (2004). Changes in biomass and root: shoot ratio of field-grown Canada thistle (Cirsium arvense), a noxious, invasive weed, with elevated $\mathrm{CO}_{2}$ : implications for control with glyphosate. Weed Science, 52(4): 584-588

Ziska LH, Goins EW (2006). Elevated atmospheric carbon dioxide and weed populations in glyphosate treated soybean. Crop Science, 46: 1354-1359.

Ziska LH (2008). Climate Change and Invasive Weeds. Powerpoint sunu,

Ziska LH (2010). Past, Present and Future Atmospheric Carbon Dioxide and the Potential Response of "Invasive" Weeds. Powerpoint sunu, Northeastern Weed Science Society Meetings, Philadelphia, Pennsylvania. 